The Journal of International Lingual, Social and Educational Sciences Year: 2019, Volume: 5, Number: 1

DOI:10.34137/jilses.584278

Geliş Tarihi: 29.06.2019

Received: 29.6 .2019

Kabul Tarihi: 06.07.2019

Accepted: 06.07.2019

Makale Türü: Araştırma Makalesi

Research Type: Research Article

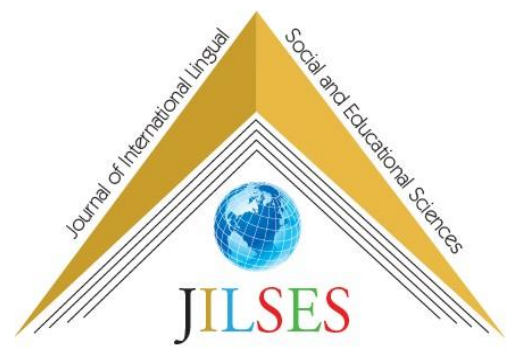

\title{
12-14 Yaş Grubu Çocukların Müziğe İlişsin Tutumları İle Sosyal Beceri Düzeyleri Arasındaki İlişkinin İncelenmesi ${ }^{1}$
}

\author{
Esra Güven² İsmail Lütfi Erol ${ }^{3}$
}

\begin{abstract}
$\ddot{O} z e t$
Araştırmada, 12-14 yaş grubu çocukların müziğe ilişskin tutumlart ile sosyal beceri düzeyleri arasındaki iliş̧kiyi belirlemek amaçlanmıştır. Araştırma 2016-2017 eğitim öğretim yllında Ankara'nın merkez ilçelerinden seçilen $424 \mathrm{klz}$ ve 379 erkek olmak üzere toplam 803 ögrenci üzerinde yürütülmüştür. Araştırmada Müziğe İlişsin Tutum Ölçeği, Çocuklar İçin Sosyal Beceri Ölçeği ve Kişisel Bilgi Formu kullanılmıştır. Verilerin analizinde SPSS 21 programından yararlanılarak frekans, yüzde, Pearson Momentler Çarpımı Korelasyon Katsayısı, t-testi, Tek yönlü varyans analizi ve Tukey HSD testi kullanılmıștır. Araștırmanın sonucuna göre çocukların müziğe ilişsin tutumları arttıkça sosyal beceri düzeyleri de artmaktadır. Ayrıca, bir müzik enstrümanı çaldığını ve bir müzik kursu aldığını belirtenlerin müziğe ilişkin tutumları ve sosyal beceri düzeyleri bir müzik enstrümanı çalmadığını ve müzik kursu almadığını belirtenlere göre daha yüksek bulunmuştur.
\end{abstract}

Anahtar Kelimeler: Müziğe ilişskin tutum, müzik beğenisi, sosyal beceri, 12-14 yaş grubu

\section{Investigation of the Relationship between Music Attitudes and Social Skill Levels of 12-14 Age Children}

\begin{abstract}
In this study, to determine the relationship between music attitudes and social skill levels of children aged 12-14 is aimed. The study was conducted on 803 students, 424 female and 379 male, selected from the central districts of Ankara in the 2016-2017 academic year. In the research Music Attitude Scale, Social Skills Scale for Children and Personal Information Form were used. In the analysis of the data, frequency, percentage, Pearson Product Moment Correlation Coefficient, $t$-test, One-way ANOVA and Tukey HSD test were used. As a result of the research, it was found that the social skill levels of children increased as their attitudes towards music increased. In addition, children who stated that they played a musical instrument and had a music course were found to have a higher attitude towards music and social skill levels than children who indicated that they did not take music course and attended a music course.
\end{abstract}

Key Words: Attitude towards music, musical preferences, social skill, 12-14 age group

\footnotetext{
${ }^{1}$ Bu makale, Esra Güven’in “12-14 Yaş Grubu Çocukların Müziğe İlişkin Tutumları İle Sosyal Beceri Düzeyleri Arasındaki İlişkinin İncelenmesi” başlıklı Dr. Öğr. Üyesi İsmail Lütfü Erol danışmanlığında hazırlanan yüksek lisans tezinden üretilmiștir.

${ }^{2}$ Öğretmen, esraguven12@ hotmail.com, http://orcid.org/0000-0003-3233-9714

${ }^{3}$ Dr. Öğr. Üyesi, Başkent Üniversitesi, ilerol.lerol@gmail.com
} 


\section{Giriş}

Müzik bir veya birden fazla insan veya çalgı sesinin tek başına veya birbirleriyle belirli bir düzenle, birbirini takip eden melodi ve ritimle, olumlu ya da olumsuz estetik duygu oluşturacak şekilde bir araya getirilmesidir (Uslu, 2006: 1). Müzik, duygu, düşünce, tasarım ve izlenimleri, belirli bir amaç ve yöntemle belirli bir güzellik anlayışına göre birleştirilmiş seslerle işleyip anlatan estetik bir bütündür (Uçan, 2005: 10). Müziğe ilişkin bu tanımlardan, müziğin bireysel veya toplulukla yapılan bir faaliyet olduğu ve bireyde estetik duyguları geliştirdiği anlaşılmaktadır. Uçan (2005:13), müziğin insan yaşamındaki işlevlerini bireysel, toplumsal, kültürel, ekonomik ve eğitimsel işlevler olmak üzere beş grupta toplamıştır. Müziğin bireysel işlevleri olarak bireyin dengeli ve doyumlu, sağlıklı ve başarılı, duyarlı ve mutlu olması için bilişsel, duyuşsal ve devinişsel yapıları üzerinde olumlu izler bırakması vurgulanırken, toplumsal işlevleri olarak da birey ile toplum arasında anlaşma, paylaşma, kaynaşma, işbirliği, birleşme ve bütünleşme sağlanmasında müziğin oynadığı roller vurgulanmaktadır. Buradan müziğin bireyin hem kişisel gelişiminde hem de toplumsal gelişimi ve ilişkilerinde önemli bir yerinin olduğu anlaşılmaktadır. Bu nedenle öncelikle bireye müziğe ilişkin olumlu bir tutum kazandırılması bireyin bireysel ve toplumsal gelişimine katkı sağlayacağı düşünülebilir. Bunların yanı sıra kişiliğin oluşumu ve şekillenmesinde önemli bir yeri olan çocukluk yıllarında çeşitli sanat etkinlikleri çocukların zihinsel, psikomotor, duygusal ve sosyal gelişimlerine olumlu katkılarda bulunur. Bu sanat etkinlikleri arasında kuşkusuz müziğin önemli bir yeri vardır. Yaşamın bir parçası olan müziğin bireyler üzerindeki etkisi sadece bireylerin müziksel gelişimleri ile sınırlı değil, müziğin genel akademik gelişim, fiziksel gelişim, sosyal gelişim ve kültürel gelişim gibi birçok farklı gelişim alanlarına etki sağlayıcı bir yönü de vardır (Kılıç, 2016). Eğitimde müziğin kullanımı, çocukların zihinsel ve ruhsal yönden dengeli yetişmesinde etkili olan ender katkılardan birini oluşturur. Bu nedenle çocuk eğitiminde müziğe yer verilmesi nitelikli bireylerin gelişmesini sağlamada oldukça önemlidir (Ergen ve Bilen, 2010). Müziği gerek dinleyerek gerek söyleyerek gerekse enstrüman kullanarak etkinliklere katılan, müziğe dönük olumlu tutum gösteren çocuk kişisel ve sosyal yönden daha olumlu bir gelişim gösterir.

Tutum, bireyin kendi dünyasının bir yönüyle ilgili güdülenme, algılama, coşku ve tanıma süreçlerinin devamlı bir örgütlemesidir. Tutumlar organize olmuş uzun süreli duygu, inanç ve davranış eğilimleridir (Cüceloğlu, 1991:84). Tutum, bireyin bir psikolojik obje ile ilgili düşünce, duygu ve davranışlarını oluşturan bir eğilimdir (Kağıtçıbaşı, 1998:84). Tutum terimi, sosyal psikolojide genel olarak "bir bireye atfedilen ve onun psikolojik bir nesneye ilişkin düşünce, duygu ve davranışlarını organize eden bir eğilime işaret etmek için kullanılmaktadır. Tutumlar kendileri gözlenemeyen, fakat gözlenebilen davranışlara yol açtığı varsayılan bazı eğilimlerdir (Kağıtçıbaşı, 2010:110). Tutumların oluşmasını etkileyen çeşitli faktörler bulunmaktadır. Aydın (1987:298) bu faktörler arasında kitle iletişim araçlarını, tutum nesnesi ile olan kişisel deneyimleri, akran, anne-baba ve öğretmen etkisi gibi faktörleri saymaktadır.

Müziğe ilişkin tutumlar konusunda yapılan araştırmaların sonuçları; tutumla akademik başarı (Erol, 1988; Öztopalan, 2007; İnceel, 2011; Wanjala, 2011; Varış ve Cesur, 2012), özgüven ve motivasyon (Kocaarslan, 2009), bir müzik aleti çalma (Brown, 1986; Uluocak ve Tufan, 2011; Afacan ve Özgür, 2016), evdeki müziksel ortam (Denac, 2008; Özmenteş, 2012), ailenin eğitim düzeyi (Nacakc1, 2006; Koca, 2013; Umuzdaş ve Umuzdaş, 2015), ailenin sosyo ekonomik düzeyi (Babacan, Babacan ve Pirgon, 2011) ve devam edilen okul türü ve sınıf düzeyi (Saruhan ve Deniz, 2011) arasında ilişkiler olduğunu ortaya koymaktadır.

Konuyla ilgili yapılan literatür çalışmasında müziğe ilişkin tutumla bazı değişkenler arasındaki ilişkinin incelendiği, ancak müziğin önemli işlevlerinden biri olan toplumsal işlev ve sosyal beceri ilişkisinin pek ele alınmadığı görülmektedir. Oysa müziğe ilişkin olumlu tutumlar ve müzik etkinlikleri bireyin sosyal becerilerinin gelişiminde etkili olabilir. Bu nedenle müziğe ilişkin tutumla sosyal beceri ilişkisinin incelenmesinde yarar görülmektedir. Kaplan’a (2013) göre, toplumsal bir varlık olan insan, sosyal çevresiyle iletişim için geliştirdiği sözcüklere, sesler aracılı̆̆ıyla duygularını, düşüncelerini, deneyimlerini anlatan değişik anlamlar yükleyerek müziğin temel yapısını oluşturur. Bu bağlamda bireyin müziğe ilişsin tutumu ile sosyal becerisi arasındaki ilişkinin incelenmesi Müzikoloji (Müzik Bilimi) alanına katkı sağlayacaktır. Çünkü Uslu'ya (2006) göre müzikoloji, insan-müzik olgusuyla ve müziği ilgilendiren bütün konularla ilgilenen bir bilim dalıdır. Bu nedenle bireyin müziğe ilişkin tutumlarını etkileyen faktörlerin belirlenmesi ve müziğe ilişkin tutumla sosyal beceri ilişkisinin incelenmesi, müzik biliminin araştırma ve inceleme konuları arasında sayılabilir.

Sosyal beceri, bireyin başkalarıyla başarılı bir şekilde etkileşimde bulunmasına olanak sağlayan davranışlardır (Bacanl1,1999). Sosyal beceriler, bireyin toplum içerisinde diğerleriyle olumlu etkileşim kurmasını sağlayan davranışlardır (Önalan Akfirat, 2006). Bireyin, öğrenerek kazandığı olumlu davranışların tamamı, sosyal beceriler olarak tanımlanır (Makar, 2016). Tosun Sümer (2008) de, sosyal becerileri kişinin, sosyal görevlerini yeterli şekilde yerine getirebilmesini sağlayan özel yetenekler olarak belirtmektedir. Bu tanımlara bakıldığı zaman sosyal beceri, gözlenebilir ve gözlenemeyen bilişsel ve duyuşsal öğeleri içeren, bireyin diğer insanlarla karşılıklı ve sağlıklı ilişkiler kurmasını sağlayan ve öğrenilebilir davranışlar olarak ortaya çıkmaktadır. 
Sosyal beceri konusunda yapılan araştırmaların sonuçları; çocukların sosyal beceri düzeylerinin; cinsiyet, yaş, sınıf düzeyi, anne-baba eğitimi ve mesleği, kardeş sayısı, akademik başarı, sosyo-ekonomik düzey ve yaşadıkları yer değişkenleri, eve süreli yayın alınıp alınmaması (Erdoğan, 2002; Akkuş, 2005; Şad, 2007; Dermez, 2008; Coşkun, 2011; Yurdakavuştu, 2012; Duran, Çeliköz ve Topaloğlu, 2013; Durualp, 2014), benlik saygısı (Yiğit ve Yılmaz, 2011; Heyworth, 2013), özyeterlik (Balyan,2009), eğitsel oyun (Gülhan, 2012), medya okuryazarlı̆̆1 (Aktı, 2011), öz kavramı düzeyi (Cerrahoğlu, 2002), ebeveynlerinin sosyal kaygıları (Tosun Sümer, 2008), kişilik özelliği (Şaşkın, 2010), işbirliğine dayalı öğrenme (Bahadır, 2011), ders başarıları (Keskin, 2007), spor yapan ve yapmayan öğrencilerin sosyal beceri düzeyleri (Arslanoğlu, 2010; Çiriş, 2014) arasında ilişkiler olduğunu ortaya koymaktadır.

Sosyal beceri konusunda yukarıda belirtilen araştırmaların bulguları, bireyin sosyal beceri düzeyi ile bazı değişkenler arasında ilişkinin olduğunu göstermektedir. Bu konudaki literatürde sosyal beceri ile müziğe ilişkin tutum arasındaki ilişkiyi inceleyen araştırmalara pek rastlanılmamaktadır. Oysa sosyal beceri birçok değişkenden etkilenebileceği gibi, müziğe ilişkin tutumdan ve müzikle ilgili etkinliklerden de etkilenebilir. Çocukların, müziksel etkinliklerle grup çalışmalarına katılarak kendilerini ifade etmeleri onların sosyalleşmesinde olumlu etki yaratacaktır. Örneğin grupla söyleme etkinliği; çocuğun sesini kullanmasını ve denetlemesini sağlayacağı, uyum becerilerini geliştirebileceği, işbirliği yapma becerisi kazandıracağı bir etkinlikken; bireysel çalgı çalması ise çocuğun kendi enerjisini olumlu yönlendirebileceği, kişisel doyum sağlayabileceği ve ritim-ezgi duygusunu geliştirebileceği türden bir etkinliktir (Bebek, 2007). 12-14 yaş dönemindeki çocukların katılacağı sanat ve müzik etkinlikleri onların o dönemde sahip olması gereken sosyal becerileri kazanmalarına katkı sağlayacaktır. Akkök (1999) bu çağdaki çocukların sahip olması gereken sosyal beceriler olarak; ilişkiyi başlatma ve sürdürme, grupla bir işi yürütme becerisi, duygulara yönelik beceriler, saldırgan davranışlarla başa çıkmaya yönelik beceriler, stres durumlarıyla başa çıkma becerileri, plan yapma ve problem çözme becerilerini belirtmektedir. Belirtilen bu becerilerin gelişmesinde kuşkusuz müzik etkinliklerinin önemli bir yeri olacaktır. Müzik etkinlikleri ile çocuk kendini ve duygularını ifade etme, başkaları ile iletişim kurma, grupla uyumlu çalışabilme özelliklerini kazanmanın yanında bu etkinlikler sayesinde saldırganlıktan ve stresten uzak durma gibi bir avantaja da sahip olacaktır.

Müzik ve müzik etkinliklerinin çocuklara yukarıda belirtilen becerileri ve özellikleri kazandırmadaki katkılarının yanında, çocuğun psiko-motor, bilişsel, duygusal ve sosyal gelişimine de katkı sağlayacağı beklenir. Çocuğun ya da bireyin gelişim sürecine paralel olarak müziksel gelişim sürecinden de söz edilebilir. Çocuklardaki müziksel gelişim, çok yönlü ve çok boyutlu bir bütünlük göstermektedir. Bu bütünlük içinde çocukların ilköğretim çağına geldiklerinde müziksel devinme, müziksel işitme, müziksel söyleme, müziksel çalma ve müziksel beğenme davranışları sergiledikleri görülmektedir (Uçan, Yıldız ve Bayraktar, 1999). Örneğin müziksel gelişim dönemlerinden 9-12 yaşlarını kapsayan dönem müziksel gelişim açısından kritik dönem olarak adlandırılmaktadır. Bu dönem, müzik bilimcileri ve eğitimcileri tarafından müziksel güçlerin biçimlendirilmesi için önemli bir dönem olarak görülmektedir. 12-13 yaşlarında ise müziksel gelişimde bireysel farklılıklar görülmeye başlamaktadır. $\mathrm{Bu}$ nedenle bu dönemdeki müziksel etkinliklerde bireysel farklılıkların dikkate alınması gerekmektedir (Özdemir ve Yıldız, 2010). Bu araştırmada çalışma grubu olarak alınan 12-14 yaş grubu gelişimsel olarak çocukluktan ergenliğe geçişin başladığı yaşlardır (Senemoğlu, 2013; Erkan, 2011;). Bu dönemde fiziksel, bilişsel, duygusal ve sosyal gelişim bakımından hızlı ve önemli değişimler yaşanmaktadır. Bu yaş grubundaki çocuklar için müziksel etkinlikler onlarda el ve göz koordinasyonu, ritim, sembolleri tanıma, dikkat geliştiren bir nitelik de taşır (Gün, Duru, Demirtaş 2016). Platon'un (M.Ö. 4.yy) Cumhuriyet adlı eserinde, gençlerin bedenleri için jimnastiğe ve ruhları için müziğe ihtiyaç duydukları belirtilmektedir (Erdem 2011). Bu nedenle bu dönemde müziksel etkinlikler erinlerin psiko-motor becerilerinin gelişimine katkı sağladığı gibi kendilerini psikolojik olarak iyi hissetmelerini de sağlayacaktır.

Bu çalışmada 12-14 yaş grubu çocukların müziğe ilişkin tutumları ile sosyal beceri düzeyleri arasındaki ilişkinin incelenmesinin yanında, çocukların hem müziğe ilişkin tutumları hem de sosyal beceri düzeyleri bazı değişkenlere (yaşanılan yer, cinsiyet, yaş, okulda algılanan başarı, anne-babanın eğitim durumu, enstrüman çalıp çalmama, müzik kursu alıp almama) göre incelenmek amaçlanmıştır. Bu amaç doğrultusunda aşağıdaki sorulara yanıt aranmıştır:

1. 12-14 yaş grubu çocukların müziğe ilişkin tutumları ile sosyal beceri düzeyleri arasında anlamlı bir ilişki var midir?

2. 12-14 yaş grubu çocukların müziğe ilişkin tutumları; yaşanılan ilçe, cinsiyet, yaş, okulda algılanan başarı, anne ve babanın eğitim durumu, herhangi bir müzik enstrümanı çalıp çalmama ve müzik kursu alıp almama değişkenlerine göre anlamlı bir farklılık göstermekte midir?

3. 12-14 yaş grubu çocukların sosyal beceri düzeyleri; yaşanılan ilçe, cinsiyet, yaş, okulda algılanan başarı, anne ve babanın eğitim durumu, herhangi bir müzik enstrümanı çalıp çalmama ve müzik kursu alıp almama değişkenlerine göre anlamlı bir farklılık göstermekte midir? 


\section{Yöntem}

\section{Araștırma Modeli}

$\mathrm{Bu}$ çalışma 12-14 yaş grubu çocukların müziğe ilişkin tutumları ile sosyal beceri düzeyleri arasındaki ilişkinin incelenmesini amaçlayan betimsel bir araştırma modelinde kurgulanmış bir tarama araştırmasıdır. Betimsel araştırmalar, olayları olduğu gibi araştırmaya ve var olan durumu belirlemeye çalışan araştırmalardır. Bu tür araştırmalarda, ele alınan olaylar ve durumlar ayrıntılı bir şekilde araştırılmakta, daha önceki olaylar ve durumlarla ilişkisi incelenerek, 'ne' oldukları betimlenmeye çalışılmaktadır (Karakaya, 2012). Bir konu ya da olaya ilişkin olarak katılımcıların görüşlerinin ya da ilgi, beceri, yetenek, tutum vb. özelliklerinin belirlendiği ve genellikle diğer araştırmalara göre daha büyük örneklem grupları üzerinde yapılan araştırmalara tarama araştırmaları denilmektedir (Büyüköztürk vd. , 2011).

\section{Çalışma Grubu}

Araştırmanın çalışma grubunu 2016 - 2017 eğitim ve öğretim yılı ikinci döneminde Milli Eğitim Bakanlığı'na bağlı Ankara'nın farklı yaşam seviyesinde yaşamakta olan ve bu nedenle Altındağ, Çankaya, Etimesgut, Mamak ve Yenimahalle merkez ilçelerinden seçilen toplam 6 ortaokulda öğrenim gören 12-14 yaş çocuklarından, 424 $(\% 52,8)$ kız ve $379(\% 47,2)$ erkek olmak üzere 803 çocuk oluşturmaktadır. Araştırmada veri toplama araçlarını eksik ya da hatalı yanıtlayan 11 çocuk araştırmaya dâhil edilmemiştir. Araştırma kapsamına alınan çocukların 293 'ü $(\% 36,5) 12$ yaşında, 234'ü $(\% 29,1) 13$ yaşında ve 276'sı $(\% 34,4)$ ise 14 yaşındadır.

\section{Veri Toplama Araçları}

Öğrenci Kişisel Bilgi Formu: Araştırmacı tarafından hazırlanan Kişisel Bilgi Formu, araştırmanın bağımsız değişkenleriyle ilgili 9 sorudan oluşmaktadır. Literatür taraması ile belirlenen bağımsız değişkenler uzman görüşü alınarak belirlenmiştir. Oluşturulan taslak form deneme uygulaması amacıyla 7. sınıflardan bir sınıfa (22 öğrenci) uygulanarak öğrencilerin formdaki soruları anlayıp anlamadıkları kontrol edilmiştir.

Müziğe İlişkin Tutum Ölçeği: Araştırmada 12-14 yaş grubu çocukların müziğe ilişkin tutumlarını belirlemek için Kocabaş (1997) tarafından geliştirilen "Müziğe İlişkin Tutum Ölçeği” kullanılmıştır. Bu ölçek ilköğretime devam eden çocukların müziğe ilişkin tutumlarını ölçmek amacıyla hazırlanmıştır. Likert tipi 3 aralıklı seçeneklerin yer aldığg1 17'si olumlu, 13'ü olumsuz 30 maddeden oluşturulan ölçeğin, Cronbach Alpha Güvenirlik Katsayısı 0,90: İki-Yarı Güvenirlik Katsayısı 0,84 şeklinde bulunmuştur. Faktör analizleri de yapılan ölçeğin çocukların müziğe ilişkin tutumlarını ölçmek için geçerli ve güvenilir bir araç olduğu saptanmıştır. Bu araştırma kapsamında ölçeğin asıl uygulamasına geçmeden önce testin tekrarı yöntemiyle güvenirliğini belirleme çalışması yapılmıştır. Ölçek iki hafta ara ile 6,7 ve 8 . sınıfa devam eden çocuklardan 57 çocuğa uygulanmış ve iki uygulama arasındaki güvenirlik katsayısı 0,86 olarak bulunmuştur. Bu durumda ölçeğin 12-14 yaş çocuklarının müziğe ilişkin tutumlarını ölçmek için kullanılabilecek geçerli ve güvenilir bir ölçek olduğu görülmüştür.

Çocuklar İçin Sosyal Beceri Ölçeği: Araştırmada 12-14 yaş çocuklarının sosyal beceri düzeylerini belirlemek amacıyla, "Çocuklar İçin Sosyal Beceri Ölçeği (ÇSBÖ)" ölçeği kullanılacaktır. Yurdakavuştu (2012) tarafindan geliştirilen ölçek, ortaokul öğrencilerinin sosyal becerilerini belirlemek amacıyla hazırlanmıştır. Toplam 20 maddeden oluşan bu ölçek 4'lü likert tipinde hazırlanmıştır. Ölçeğin kapsam geçerliliğinin sağlanması için faktör analizi yapılmış ve madde toplam korelasyonları hesaplanmıştır. Ölçeğin faktör analizi sonucunda tek faktörden oluştuğuna karar verilmiştir. Ölçeğin tamamına ilişkin cronbach alpha güvenirlik katsayısı 0,87 olarak bulunmuştur. $\mathrm{Bu}$ araştırma kapsamında ölçeğin asıl uygulamasına geçmeden önce testin tekrarı yöntemiyle güvenirliğini belirleme çalışması yapılmıştır. Ölçek iki hafta ara ile 6,7 ve 8. sınıfa devam eden çocuklardan 57 çocuğa uygulanmış ve iki uygulama arasındaki güvenirlik katsayısı 0,83 olarak bulunmuştur. Bu durumda sosyal beceri ölçeğinin 12-14 yaş çocukların sosyal beceri düzeylerini ölçmek için kullanılabilecek geçerli ve güvenilir bir ölçek olduğu görülmüştür.

\section{Verilerin Toplanması}

Verilerin toplanma aşamasında “Öğrenci Kişisel Bilgi Formu”, "Müziğe İlişkin Tutum Ölçeği” ve "Çocuklar İçin Sosyal Beceri Ölçeği”nin uygulanabilmesi için Ankara Valiliği ve İl Milli Eğitim Müdürlügü'nden gerekli izinler alınarak ve araştırma kapsamındaki okullara gidilerek uygulanmıştır. Uygulama sırasında çocuklara ölçeklerin ne şekilde yanıtlanacağı açıklanarak sorulara objektif ve içten cevaplar verebilmeleri sağlanmıştır.

\section{Verilerin Analizi}

Araştırmada verilerin çözümlenmesi sürecinin ilk aşamasında veri toplama araçlarından elde edilen veriler bilgisayar ortamına aktarılmış ve SPSS 21 programı kullanılarak çözümlenmiştir. Müziğe ilişkin tutum ile sosyal beceri düzeyi arasındaki ilişkinin incelenmesi için Pearson Momentler Çarpımı Korelasyon tekniğinden yararlanılmıştır. Araştırmanın bağımlı değişkenlerinin, bağımsız değişkenlere göre değişimini belirlemek amacıyla normal dağılım gösteren ve varyansları homojen olan değişkenlerde grupların iki olması durumunda 
(örneğin cinsiyet gibi) $t$ testi ve grupların ikiden fazla olması durumunda ise (örneğin yaş düzeyi gibi) Tek Yönlü Varyans Analizi kullanılmışır. Varyans analizi sonucunda farkın anlamlı çıkması halinde bu farkın hangi gruplar arasında olduğunu belirlemek amacıyla Tukey HSD testinden yararlanılmıştır.

\section{Bulgular}

Bu bölümde, önce araştırma kapsamına alınan 12-14 yaş çocuklarının müziğe ilişkin tutumları ile sosyal beceri düzeyleri arasındaki ilişkiye yönelik bulgular, sonra da araştırmanın diğer değiş̧kenlerine göre müziğe ilişsin tutum ve sosyal beceri düzeyleri arasındaki farklara yönelik bulgulara yer verilmiştir.

\section{Müziğe İliş̧kin Tutum İle Sosyal Beceri Düzeyi Arasındaki İlişsi}

Araştırmada verilerin istatistiksel analizlerine başlanırken öncelikle verilerin normal bir dağıllım gösterip göstermediği incelenmiştir. Bunun için Skewness ve Kurtosis (çarpıklık ve basıklık) değerlerine bakılmıştır. Müziğe İlişkin Tutum Ölçeğinden elde edilen verilerin Skewness değerleri -,375 ile ,086 arasında, Kurtosis değerleri ise -,791 ile ,172 arasında bulunmuştur. Sosyal Beceri Ölçeğinden elde edilen verilere ilişkin Skewness değerleri -,621 ile ,086 arasında, Kurtosis değerleri ise ,709 ile ,172 arasında bulunmuştur. Bu değerlerin -1,5 ile $+1,5$ arasında olması verilerin normal dağılıma sahip olduğunu göstermektedir (Tabachnick ve Fidell, 2013). Bu durumda araştırmada toplanan ve üzerinde istatistiksel işlemler yapılacak verilerin normal dağılım gösterdiği belirlenmiştir.

Araştırma kapsamına alınan çocukların Müziğe İlişkin Tutum Ölçeğinden ve Sosyal Beceri Ölçeğinden almış oldukları puanlar arasındaki ilişki Pearson Momentler Çarpımı Korelasyon Katsayısı ile hesaplanmış ve çocukların müziğe ilişkin tutum puanları ile sosyal beceri puanları arasında pozitif yönde anlamlı bir ilişki $(\mathrm{r}=0.419, \mathrm{p}<.01)$ bulunmuştur. Yani çocukların müziğe ilişkin tutumları arttıkça sosyal beceri düzeyleri de artmaktadır.

\section{Araştırmada Ele Alınan Değişkenlere Göre Çocukların Müziğe İlişsin Tutumları ve Sosyal Beceri Düzeyleri}

Aşağıda araştırmada ele alınan değişkenlere göre müziğe ilişkin tutum ve sosyal beceri puanları arsındaki farklara ilişkin bulgular verilmiş̧ir.

\section{1. Çocukların Yaşadıkları İlçelere Göre Müziğe İlişkin Tutumları ve Sosyal Beceri Düzeyleri}

Araştırmanın çalışma grubunu oluşturan çocukların Ankara ilinde yaşadıkları merkez ilçelere göre müziğe ilişkin tutum ve sosyal beceri puanlarının aritmetik ortalaması ve standart sapmaları Tablo 1'de verilmiştir.

Tablo-1. Yaşanılan İlçeye Göre Çocukların Müziğe İlişkin Tutum ve Sosyal Beceri Puanlarının Aritmetik Ortalamaları ve Standart Sapmaları

\begin{tabular}{|c|c|c|c|c|}
\hline Değişkenler & Yaşanılan İlçe & $\mathbf{n}$ & $\mathbf{x}$ & $\mathbf{s}$ \\
\hline \multirow{6}{*}{ Müziğe İlişkin Tutum } & Altındağ & 152 & 63,6118 & 13,55492 \\
\hline & Çankaya & 178 & 63,1348 & 14,06297 \\
\hline & Etimesgut & 168 & 67,7679 & 13,97302 \\
\hline & Mamak & 144 & 65,3194 & 14,48397 \\
\hline & Yenimahalle & 161 & 70,0994 & 11,84969 \\
\hline & Toplam & 803 & 65,9826 & 13,83217 \\
\hline \multirow{6}{*}{ Sosyal Beceri } & Altındağ & 152 & 62,0461 & 9,26386 \\
\hline & Çankaya & 178 & 60,4607 & 10,27427 \\
\hline & Etimesgut & 168 & 61,6488 & 9,04026 \\
\hline & Mamak & 144 & 62,1944 & 11,67286 \\
\hline & Yenimahalle & 161 & 63,6522 & 8,98420 \\
\hline & Toplam & 803 & 61,9601 & 9,89828 \\
\hline
\end{tabular}

Tablo 1'de görüldüğü gibi Yenimahalle ilçesinde yaşayan çocukların müziğe ilişkin tutum puanlarının diğerlerinden daha yüksek olduğu ve bunu sirasıyla Etimesgut, Mamak, Altındağ ve Çankaya ilçelerinde yaşayan çocukların izlediği görülmektedir. Sosyal Beceri puanlarına bakıldığında da Yenimahalle'nin ilk sırada olduğu ve bunu sırasıyla Mamak, Altındağ, Etimesgut ve Çankaya ilçelerinin izlediği görülmektedir. Puanlarda gözlenen bu farklılığın istatistiksel olarak anlamlı olup olmadığını saptamak için yapılan Tek Yönlü Varyans Analizi sonucunda çocukların yaşadıkları yere göre müziğe ilişkin tutum puanlarında istatistiksel olarak anlamlı 
bir fark $(\mathrm{F}=7,592, \mathrm{p}<.001)$ bulunurken, sosyal beceri puanlarında anlamlı bir fark $(\mathrm{F}=2,276, \mathrm{p}>.05)$ bulunmamıştır.

Yaşanılan yere göre müziğe ilişkin tutum puanlarındaki farkın hangi grupların puan ortalamaları arasında olduğunu belirlemek amacıyla yapılan Tukey HSD testi sonucunda Yenimahalle'de yaşayan çocukların $(\mathrm{x}=70,0994)$ Altındağ $(\mathrm{x}=63,6118)$, Çankaya $(\mathrm{x}=63,1348)$ ve Mamak'ta yaşayan çocuklara $(\mathrm{x}=65,3194)$ göre, Etimesgut'ta yaşayan çocukların $(x=67,7679)$ da Çankaya'da yaşayanlara $(x=63,1348)$ göre müziğe yönelik tutumları daha yüksek bulunmuştur.

\section{2. Çocukların Cinsiyetlerine Göre Müziğe İlişkin Tutumları ve Sosyal Beceri Düzeyleri}

Araştırmanın çalışma grubunu oluşturan çocukların cinsiyetlerine göre müziğe ilişkin tutum ve sosyal beceri puanlarının aritmetik ortalamaları, standart sapmaları ve t-testi sonuçları Tablo 2'de verilmiştir.

Tablo-2. Çocukların Cinsiyetlerine Göre Müziğe İlişkin Tutum ve Sosyal Beceri Puanlarının Aritmetik Ortalamaları, Standart Sapmaları ve t Değerleri

\begin{tabular}{|c|c|c|c|c|c|c|}
\hline Değişkenler & Cinsiyet & $\mathbf{n}$ & $\mathbf{x}$ & $\mathbf{S}$ & $\mathbf{t}$ & $\mathbf{p}$ \\
\hline \multirow[t]{2}{*}{ Müziğe İlişkin Tutum } & $\mathrm{K}_{1 \mathrm{z}}$ & 424 & 68,7406 & 13,16754 & 6,110 & ,000* \\
\hline & Erkek & 379 & 62,8971 & 13,92259 & & \\
\hline \multirow[t]{2}{*}{ Sosyal Beceri } & $\mathrm{K} 1 \mathrm{Z}$ & 424 & 63,9269 & 9,04033 & 6,088 &, $000^{*}$ \\
\hline & Erkek & 379 & 59,7599 & 10,35496 & & \\
\hline
\end{tabular}

$* \mathrm{p}<.001$

Tablo 2'de görüldüğü gibi kızların müziğe ilişkin tutum puan ortalamaları $(\mathrm{x}=68,7406)$ ve sosyal beceri puan ortalamaları $(x=63,9269)$, erkeklerin müziğe ilişkin tutum puan ortalamaları $(x=62,8971)$ ve sosyal beceri puan ortalamalarından $(\mathrm{x}=59,7599)$ daha yüksek bulunmuştur.

\section{3. Çocukların Yaşlarına Göre Müziğe İlişkin Tutumları ve Sosyal Beceri Düzeyleri}

Araştırmanın çalışma grubunu oluşturan çocukların yaşlarına göre müziğe ilişkin tutum ve sosyal beceri puanlarının aritmetik ortalamaları ve standart sapmaları Tablo 3'te verilmiştir.

Tablo-3. Çocukların Yaşlarına Göre Müziğe İlişkin Tutum ve Sosyal Beceri Puanlarının Aritmetik Ortalamaları ve Standart Sapmaları

\begin{tabular}{lcccc}
\hline Değişkenler & Yaş & $\mathbf{n}$ & $\mathbf{x}$ & \multicolumn{1}{c}{$\mathbf{s}$} \\
\hline \multirow{3}{*}{ Müziğe İlişkin Tutum } & 12 & 293 & 67,7474 & 13,27880 \\
\cline { 2 - 5 } & 13 & 234 & 68,9744 & 13,62871 \\
\cline { 2 - 5 } & 14 & 276 & 61,5725 & 13,52513 \\
\cline { 2 - 5 } Sosyal Beceri & Toplam & 803 & 65,9826 & 13,83217 \\
\cline { 2 - 5 } & 12 & 293 & 63,8703 & 9,50686 \\
\cline { 2 - 5 } & 13 & 234 & 61,6197 & 10,29003 \\
\cline { 2 - 5 } & 14 & 276 & 60,2210 & 9,64526 \\
\cline { 2 - 5 } & Toplam & 803 & 61,9601 & 9,89828 \\
\hline
\end{tabular}

Tablo 3'te görüldüğü gibi 13 yaşındaki çocukların müziğe ilişkin tutum puanlarının diğerlerinden daha yüksek olduğu ve bunu sırasıyla 12 ve 14 yaş çocuklarının izlediği görülmektedir. Sosyal Beceri puanlarına bakıldığında ise 12 yaş çocuklarının ilk sırada yer aldığı ve bunu sırasıyla 13 ve 14 yaş çocuklarının izlediği görülmektedir. Puanlarda gözlenen bu farklılığın istatistiksel olarak anlamlı olup olmadığını saptamak için yapılan Tek Yönlü Varyans Analizi sonucunda çocukların yaşa göre hem müziğe ilişkin tutum puanlarında $(\mathrm{F}=23,092, \mathrm{p}<.001)$ hem de sosyal beceri puanlarında istatistiksel olarak anlamlı bir fark $(\mathrm{F}=10,077, \mathrm{p}>$.05) bulunmuştur.

Yaşa göre müziğe ilişkin tutum ve sosyal beceri puanlarındaki farkın hangi grupların puan ortalamaları arasında olduğunu belirlemek amacıyla yapılan Tukey HSD testi sonucunda 13 yaşındaki çocukların $(x=68,9744) 14$ yaşındakilere $(x=61,5725)$ göre müziğe yönelik tutumları daha yüksek bulunmuştur. 12 yaşındaki çocukların sosyal beceri düzeyi ise $(x=63,8703) 13$ yaş $(x=61,6197)$ ve 14 yaş $(x=60,2210)$ çocuklarının sosyal beceri düzeyinden daha yüksek bulunmuştur. 


\section{4. Çocukların Okuldaki Başarı Algılarına Göre Müziğe İlişkin Tutumları ve Sosyal Beceri Düzeyleri}

Araştırmanın çalışma grubunu oluşturan çocukların okuldaki başarı algılarına göre müziğe ilişkin tutum ve sosyal beceri puanlarının aritmetik ortalamaları ve standart sapmaları Tablo 4 'te verilmiştir.

Tablo-1. Çocukların Okuldaki Başarı Algılarına Göre Müziğe İlişkin Tutum ve Sosyal Beceri Puanlarının Aritmetik Ortalamaları ve Standart Sapmaları

\begin{tabular}{llrrc}
\hline Değiş̧kenler & Okuldaki Başarı Algısı & $\mathbf{n}$ & $\mathbf{x}$ & \multicolumn{1}{c}{ S } \\
\hline \multirow{3}{*}{ Müziğe İlişkin Tutum } & Yüksek & 226 & 73,3496 & 11,69148 \\
\cline { 2 - 5 } & Orta & 484 & 65,5579 & 12,54337 \\
\cline { 2 - 4 } & Düşük & 93 & 50,2903 & 11,15268 \\
\cline { 2 - 4 } Sosyal Beceri & Toplam & 803 & 65,9826 & 13,83217 \\
\cline { 2 - 4 } & Yüksek & 226 & 65,7035 & 9,56687 \\
\cline { 2 - 4 } & Orta & 484 & 61,7707 & 8,88849 \\
\cline { 2 - 4 } & Düşük & 93 & 53,8495 & 10,69432 \\
\hline & Toplam & 803 & 61,9601 & 9,89828 \\
\hline
\end{tabular}

Tablo 4'te görüldüğü gibi okuldaki başarı algısı yüksek olan çocukların müziğe ilişkin tutum puanlarının diğerlerinden daha yüksek olduğu ve bunu sırasıyla okuldaki başarı algısı orta ve düşük olan çocukların izlediği görülmektedir. Sosyal Beceri puanlarına bakıldığında ise yine aynı şeklide okuldaki başarı algısı yüksek olan çocuklarının ilk sırada yer aldığı ve bunu sırasıyla okuldaki başarısını orta ve düşük algılayan çocukların izlediği görülmektedir. Puanlarda gözlenen bu farklılığın istatistiksel olarak anlamlı olup olmadığını belirlemek için yapılan Tek Yönlü Varyans Analizi sonucunda çocukların okuldaki başarı algılarına göre hem müziğe ilişkin tutum puanlarında $(\mathrm{F}=119,31, \mathrm{p}<.001)$ hem de sosyal beceri puanlarında istatistiksel olarak anlamlı bir fark $(\mathrm{F}=53,712, \mathrm{p}>.05)$ bulunmuştur.

Okuldaki başarı algısına göre müziğe ilişkin tutum ve sosyal beceri puanlarındaki farkın hangi grupların puan ortalamaları arasında olduğunu belirlemek amacıyla yapılan Tukey HSD testi sonucunda okuldaki başarı algıS1 yüksek olan çocukların $(x=73,3496)$ orta $(x=65,5579)$ ve düşük $(x=50,2903)$ olanlara göre, orta olanların $(x=65,5579)$ düşük olanlara $(x=50,2903)$ göre müziğe yönelik tutumları anlamlı olarak daha yüksek bulunmuştur. Sosyal beceri puanları açısından değerlendirildiğinde ise okuldaki başarı algısı yüksek olanların $(x=65,7035)$ orta $(x=61,7703)$ ve düşük $(x=53,8495)$ olanlara göre, orta olanların $(x=61,7703)$ düşük olanlara göre $(x=53,8495)$ sosyal beceri puanları anlamlı olarak daha yüksektir.

\section{5. Çocukların Annelerinin Eğitim Durumlarına Göre Müziğe İlişkin Tutumları ve Sosyal Beceri Düzeyleri}

Araştırmanın çalışma grubunu oluşturan çocukların annelerinin eğitim durumlarına göre müziğe ilişkin tutum ve sosyal beceri puanlarının aritmetik ortalamaları ve standart sapmaları Tablo 5'de verilmiştir.

Tablo-5. Çocukların Annelerinin Eğitim Durumlarına Göre Müziğe İlişkin Tutum ve Sosyal Beceri Puanlarının Aritmetik Ortalamaları ve Standart Sapmaları

\begin{tabular}{llllc}
\hline Değișkenler & $\begin{array}{l}\text { Annenin Eğitim } \\
\text { Durumu }\end{array}$ & $\mathbf{n}$ & $\mathbf{x}$ & S \\
\hline \multirow{3}{*}{ Müziğe İlişkin Tutum } & Okur-Yazar & 15 & 69,8000 & 11,97736 \\
\cline { 2 - 5 } İlkokul & 188 & 66,3830 & 13,27787 \\
\cline { 2 - 5 } & Ortaokul & 155 & 64,7742 & 13,03170 \\
\cline { 2 - 5 } & Lise & 224 & 66,8884 & 14,18396 \\
\cline { 2 - 5 } Sosyal Beceri & Üniversite & 221 & 65,3122 & 14,56856 \\
\cline { 2 - 5 } & Toplam & 803 & 65,9826 & 13,83217 \\
\hline & Okur-Yazar & 15 & 67,5333 & 7,48204 \\
\cline { 2 - 5 } & İlkokul & 188 & 61,9255 & 9,44756 \\
\cline { 2 - 5 } & Ortaokul & 155 & 61,4129 & 9,83024 \\
\cline { 2 - 5 } & Lise & 224 & 62,5000 & 9,87546 \\
\cline { 2 - 5 } & Üniversite & 221 & 61,4480 & 10,40905 \\
\cline { 2 - 5 } & Toplam & 803 & 61,9601 & 9,89828 \\
\hline
\end{tabular}


Tablo 5'de görüldüğü gibi çocukların anneleri okur-yazar olanların müziğe ilişkin tutum puanlarının diğerlerinden daha yüksek olduğu ve bunu sırasıyla lise, ilkokul, üniversite ve ortaokul mezunlarının izlediği görülmektedir. Sosyal Beceri puanlarına bakıldığında da annesi okul-yazar olanların ilk sırada olduğu ve bunu sırasıyla lise, ilkokul, üniversite ve ortaokul mezunlarının izlediği görülmektedir. Puanlarda gözlenen bu farklılığın istatistiksel olarak anlamlı olup olmadığını belirlemek için yapılan Tek Yönlü Varyans Analizi sonucunda çocukların annelerinin eğitim durumlarına göre hem müziğe ilişkin tutum puanlarında $(\mathrm{F}=0,991$, $\mathrm{p}>.05)$ hem de sosyal beceri puanlarında $(\mathrm{F}=1,627, \mathrm{p}>.05)$ istatistiksel olarak anlamlı bir fark bulunmamıştır.

\section{6. Çocukların Babalarının Eğitim Durumlarına Göre Müziğe İlişkin Tutumları ve Sosyal Beceri Düzeyleri}

Araştırmanın çalışma grubunu oluşturan çocukların babalarının eğitim durumlarına göre müziğe ilişkin tutum ve sosyal beceri puanlarının aritmetik ortalamaları ve standart sapmaları Tablo 6'da verilmiştir.

Tablo-2. Çocukların Babalarının Eğitim Durumlarına Göre Müziğe İlişkin Tutum ve Sosyal Beceri Puanlarının Aritmetik Ortalamaları ve Standart Sapmaları

\begin{tabular}{llccc}
\hline Değişkenler & $\begin{array}{l}\text { Babanın Ĕgitim } \\
\text { Durumu }\end{array}$ & $\mathbf{n}$ & $\mathbf{x}$ & $\mathbf{s}$ \\
\hline \multirow{3}{*}{ Müziğe İlişkin Tutum } & Okur-Yazar & 10 & 72,1000 & 13,06777 \\
\cline { 2 - 5 } & İlkokul & 114 & 65,5526 & 13,23517 \\
\cline { 2 - 5 } & Ortaokul & 157 & 64,9618 & 12,63232 \\
\cline { 2 - 5 } & Lise & 230 & 67,6739 & 13,30472 \\
\cline { 2 - 5 } S̈̈niversite & 292 & 65,1575 & 14,97636 \\
\cline { 2 - 5 } & Toplam & 803 & 65,9826 & 13,83217 \\
\hline & Okur-Yazar & 10 & 70,5000 & 6,00463 \\
\cline { 2 - 5 } & İlkokul & 114 & 61,5439 & 10,14683 \\
\cline { 2 - 5 } & Ortaokul & 157 & 61,0510 & 9,71306 \\
\cline { 2 - 5 } & Lise & 230 & 63,1435 & 9,37577 \\
\cline { 2 - 5 } & Üniversite & 292 & 61,3870 & 10,23324 \\
\cline { 2 - 5 } & Toplam & 803 & 61,9601 & 9,89828 \\
\hline
\end{tabular}

Tablo 6'da görüldüğü gibi çocukların babaları okur-yazar olanların müziğe ilişkin tutum puanlarının diğerlerinden daha yüksek olduğu ve bunu sırasıyla lise, ilkokul, üniversite ve ortaokul mezunlarının izlediği görülmektedir. Sosyal Beceri puanlarına bakıldığında da babası okul-yazar olanların ilk sırada olduğu ve bunu sırasıyla lise, ilkokul, üniversite ve ortaokul mezunlarının izlediği görülmektedir. Babalarının eğitim durumu okur-yazar olanların sayısı yetersiz olduğu $(n=10)$ için bu grup varyans analizinde hesaplamaya dâhil edilmemiştir. Yapılan Tek Yönlü Varyans Analizi sonucunda çocukların babalarının eğitim durumlarına göre hem müziğe ilişkin tutum puanlarında $(F=1,812, p>.05)$ hem de sosyal beceri puanlarında $(F=1,908, p>.05)$ istatistiksel olarak anlamlı bir fark bulunmamıştır.

\section{7. Çocukların Bir Müzik Enstrümanı Çalıp Çalmama Durumlarına Göre Müziğe İlişkin Tutumları ve Sosyal Beceri Düzeyleri}

Araştırmanın çalışma grubunu oluşturan çocukların bir müzik enstrümanı çalıp çalmama durumlarına göre müziğe ilişkin tutum ve sosyal beceri puanlarının aritmetik ortalamaları, standart sapmaları ve t-testi sonuçları Tablo 7'de verilmiştir.

Tablo-7. Çocukların Bir Müzik Enstrümanı Çalıp Çalmama Durumlarına Göre Müziğe İlişkin Tutum ve Sosyal Beceri Puanlarının Aritmetik Ortalamaları, Standart Sapmaları ve t Değerleri

\begin{tabular}{lcccccc}
\hline Değişkenler & $\begin{array}{c}\text { Enstrüman } \\
\text { Çalma }\end{array}$ & $\mathbf{n}$ & $\mathbf{x}$ & $\mathbf{s}$ & $\mathbf{t}$ & $\mathbf{p}$ \\
\hline Müziğe İlişkin Tutum & Evet & 218 & 76,3440 & 8,54298 & 14,564 &, $000^{*}$ \\
\cline { 2 - 6 } & Hayır & 585 & 62,1214 & 13,43951 & & \\
\hline Sosyal Beceri & Evet & 218 & 64,7569 & 8,06886 & 4,959 & \multirow{2}{*}{$000^{*}$} \\
\cline { 2 - 5 } & Hayır & 585 & 60,9179 & 10,31259 & & \\
\hline
\end{tabular}


Tablo 7'de görüldüğ̈̈ gibi flüt ve melodika dışında bir müzik enstrümanı çaldığını belirten çocukların müziğe ilişkin tutum puan ortalamaları $(x=76,3440)$ ve sosyal beceri puan ortalamaları $(x=64,7569)$, müzik enstrümanı çalmadığını belirtenlerin müziğe ilişkin tutum puan ortalamaları $(x=62,1214)$ ve sosyal beceri puan ortalamalarından $(x=60,9179)$ anlamlı olarak daha yüksek bulunmuştur.

\section{8. Çocukların Bir Müzik Kursu Alıp Almama Durumlarına Göre Müziğe İlişkin Tutumları ve Sosyal Beceri Düzeyleri}

Araştırmanın çalışma grubunu oluşturan çocukların bir müzik kursu alıp almama durumlarına göre müziğe ilişkin tutum ve sosyal beceri puanlarının aritmetik ortalamaları, standart sapmaları ve t-testi sonuçları Tablo 8'de verilmiştir.

Tablo-8. Çocukların Bir Müzik Kursu Alıp Almama Durumlarına Göre Müziğe İlişkin Tutum ve Sosyal Beceri Puanlarının Aritmetik Ortalamaları, Standart Sapmaları ve t Değerleri

\begin{tabular}{lcccccc}
\hline Değişkenler & Müzik Kursu & $\mathbf{n}$ & $\mathbf{x}$ & $\mathbf{s}$ & $\mathbf{t}$ & $\mathbf{p}$ \\
\hline Müziğe İlişkin Tutum & Evet & 197 & 77,8020 & 8,79914 & 15,802 & \multirow{2}{*}{, $000^{*}$} \\
\cline { 2 - 6 } & Hayır & 606 & 62,1403 & 12,97188 & & \\
\hline \multirow{2}{*}{ Sosyal Beceri } & Evet & 197 & 65,5330 & 8,16133 & 5,956 & \multirow{2}{*}{, $000^{*}$} \\
\cline { 2 - 6 } & Hayır & 606 & 60,7987 & 10,13866 & & \\
\hline
\end{tabular}

*p<.001

Tablo 8'de görüldüğü gibi bir müzik kursu aldığını belirten çocukların müziğe ilişkin tutum puan ortalamaları $(x=77,8020)$ ve sosyal beceri puan ortalamaları $(x=65,5330)$, müzik kursu almadığını belirtenlerin müziğe ilişkin tutum puan ortalamaları $(x=62,1403)$ ve sosyal beceri puan ortalamalarından $(x=60,7987)$ anlamlı olarak daha yüksek bulunmuştur.

\section{Tartışma}

Araştırma kapsamına alınan 12-14 yaş çocuklarının müziğe ilişkin tutumlarıyla sosyal beceri düzeyleri arasındaki ilişkinin incelenmesi sonucunda çocukların müziğe ilişkin tutumları ve sosyal beceri düzeyleri arasında pozitif yönde anlamlı bir ilişki bulunmuştur. Bu bulgu, çocukların müziğe ilişkin tutumlarının arttıkça sosyal beceri düzeylerinin de arttığını göstermektedir. Buradan müziğe yönelik olumlu tutumlar kazandırmanın sosyal beceri üzerinde olumlu etkisinin olacağı ve çocukların sosyal becerilerinin gelişmesine katkı sağlayacağı söylenebilir. Müziğe ilişkin olumlu tutumları geliştirmenin önemli bir yolu da çocukları müziksel etkinliklere yöneltmek ve müziği sevmelerini sağlamaktır. Guilmartin'e (2015) göre, çocuklarla müzik yapmak onların sosyal-duygusal öğrenmelerini desteklemenin kolay ve eğlenceli bir yoludur. Aşağıda araştırmada ele alınan değişkenlere (yaşanılan yer, cinsiyet, yaş, okuldaki başarı algısı, anne-baba eğitim durumu, enstrüman çalıp çalmama ve müzik kursu alıp almama) göre müziğe ilişkin tutum ve sosyal beceri ile ilgili bulgular tartışılmıştır.

Çocukların müziğe yönelik tutumlarının yaşanılan yere göre farklılık gösterdiği, Yenimahalle'de yaşayan çocukların Altındağ, Çankaya ve Mamak'ta yaşayan çocuklara göre, Etimesgut'ta yaşayan çocukların da Çankaya'da yaşayanlara göre müziğe yönelik tutumları daha yüksek bulunmuştur. Araştırmanın bu konudaki bulgusunun beklentilerle pek uyuşmadığı söylenebilir. Özellikle sosyo-ekonomik düzey bakımından diğer ilçelere göre daha yüksek bir görünüm sergileyen Çankaya ilçesinde yaşayan çocukların müziğe yönelik tutumlarının daha yüksek olacağı beklenirken, Yenimahalle ve Etimesgut ilçelerinde yaşayan çocukların müziğe ilişkin tutumlarının daha yüksek olması ilginç bir bulgudur. Afacan ve Özgür'ün (2016) araştırmasında, 6 ve 7. Sınıfa devam eden çocukların müzik dersine ilişkin tutumlarının okulların içinde bulunduğu sosyo-ekonomik çevreye göre anlamlı bir şekilde farklılaşı̆̆̆, sosyo-ekonomik düzeyi orta olan çocukların sosyo-ekonomik düzeyi yüksek olanlara göre müziğe ilişkin tutumlarının daha olumlu olduğu bulunmuştur. $\mathrm{Bu}$ bulgu, bu araştırmanın bu konudaki bulgusu ile paralellik göstermektedir. Diğer bir çalışmada da (Babacan, Babacan ve Pirgon, 2011), ilköğretime devam eden çocuklarının müzik dersine ilişkin tutumlarının, okudukları okulların sosyo-ekonomik düzeylerine göre farklılık gösterdiği, sosyo-ekonomik düzeyi yükseldikçe çocukların müzik dersine iliş̧kin tutumlarında da artış olduğu belirlenmiştir. Bu da beklenen yönde bir bulgudur. Ancak bu araştırmadan elde edilen ve bu konudaki diğer araştırmaların bulguları müziğe ilişkin tutumda, içinde yaşanılan çevrenin sosyo-ekonomik düzeyinin kesin belirleyici bir faktör olmadığını göstermektedir. Çocukların yaşadıkları ilçeye göre sosyal beceri düzeylerinin incelenmesi sonucu elde edilen bulguya göre, yaşanılan yere göre sosyal beceri düzeyinin anlamlı farklılık göstermediği ortaya çıkmıştır. Çeliköz, Duman ve Topaloğlu'nun (2013) ortaokul öğrencileri üzerinde yaptıkları araştırmada öğrencilerin sosyal beceri düzeylerinin yaşadıkları yere göre değişmediği belirlenmiştir. Bu bulgu, araştırmanın bu konudaki bulgusunu destekler niteliktedir.

Araştırmanın çalışma grubunu oluşturan çocukların cinsiyetlerine göre müziğe ilişkin tutumlarının anlamlı farklılık gösterdiği, kızların müziğe ilişkin tutumlarının erkeklerden daha yüksek olduğu bulunmuştur. 
Araştırmanın bu bulgusunu destekleyen bazı araştırma bulguları bulunmaktadır. Öztopalan (2007), Kaya (2010), İnceel (2011), Uluocak ve Tufan (2011), Saruhan ve Deniz (2011), Özmenteș (2012), Afacan ve Özgür (2016) ve Aslantaş (2016) tarafından yapılan araştırmalarda kızların müziğe ilişkin tutumlarının erkeklerden daha yüksek olduğu bulunmuştur. Diğer yandan araştırmanın çalışma grubunu oluşturan çocukların cinsiyetlerine göre sosyal beceri düzeylerinin anlamlı farklılık gösterdiği, kız çocuklarının sosyal beceri düzeylerinin erkeklerden daha yüksek olduğu bulunmuştur. Akkuş (2005), Dermez (2008), Yiğit (2008), Balyan (2009), Arslanoğlu (2010), Aktı (2011), Yurdakavuştu (2012), Çeliköz, Duran ve Topaloğlu (2013) ve Durualp (2014) tarafindan yapılan araştırmalar, araştırmanın bu bulgusunu desteklemektedir. Bu araştırmalar kız çocuklarının sosyal beceri düzeylerinin erkeklerden daha yüksek olduğunu ortaya koymaktadır.

Araştırmanın çalışma grubunu oluşturan çocukların yaşlarına göre müziğe ilişkin tutumları arasında anlamlı bir farklılığın olduğu belirlenmiştir. 13 yaşındaki çocukların 14 yaşındakilere göre müziğe yönelik tutumları daha yüksektir. Afacan ve Özgür'ün (2016) yaptığı araştırmada 6. sınıf öğrencilerinin müziğe yönelik tutumlarının 7. sınıf öğrencilerinden yüksek olduğu, benzer bir şekilde Aslantaş’ın (2016) yaptığı araştırmada da 8. sınıf öğrencilerinin müziğe ilişkin tutumlarının 6. ve 7. sınıf öğrencilerinden düşük olduğu belirlenmiştir. Bu bulgularla bu araştırmanın bulguları arasında bir paralellik görülmektedir. Yaşa göre sosyal beceri düzeylerinde anlamlı bir fark olduğu, 12 yaş grubu çocukların sosyal beceri düzeylerinin 13 ve 14 yaş grubu çocuklarına göre daha yüksek olduğu ortaya çıkmıştır. Yani yaş düzeyi arttıkça sosyal beceri düzeyinde düşüş görülmektedir. Çiriş'in (2014) araştırmasında da bu bulgunun tersi bir bulgu elde edilmiştir. Adı geçen araştırmaya göre 8. sınıf öğrencilerinin sosyal beceri düzeyleri 6. ve 7. sinıf öğrencilerinden, 7. sınıf öğrencilerinin de 6. sinıf öğrencilerinden yüksek bulunmuştur. Ortaokul öğrencilerinin yaş veya sınıf düzeylerine göre sosyal beceri düzeyleri konusunda daha kesin bilgilere ulaşmak için daha detaylı araştırmalara ihtiyaç olduğu söylenebilir.

Araştırmanın çalışma grubunu oluşturan çocukların okuldaki başarı algılarına göre müziğe ilişkin tutumları arasında anlamlı bir fark olduğu bulunmuştur. Okuldaki başarı algısı yüksek olan çocukların müziğe ilişkin tutumları, başarı algısı orta ve düşük olan çocuklara, okuldaki başarı algısı orta olan çocukların da düşük olanlara göre müziğe ilişkin tutumları daha yüksek bulunmuştur. Yani çocukların okuldaki başarı algısı yükseldikçe müziğe ilişkin tutumları artış göstermektedir. Diğer bir değişle müziğe ilişkin tutumlar arttıkça okuldaki başarı algılaması da artmaktadır. Araştırmanın bu bulgusu beklentiler doğrultusundadır. Okuldaki başarı algısına göre çocukların sosyal beceri düzeylerinin de farklılık gösterdiği bulunmuştur. Müziğe ilişkin tutumda olduğu gibi okuldaki başarı algısı yüksek olan çocukların sosyal beceri düzeyleri orta ve düşük olanlara göre, okuldaki başarı algısı orta olanların da düşük olanlara göre sosyal beceri düzeyleri daha yüksek bulunmuştur. Yani çocukların okuldaki başarı algısı yükseldikçe sosyal beceri düzeyleri de yükselmektedir. Diğer bir değişle sosyal beceri düzeyleri yükseldikçe okuldaki başarı algıları da artmaktadır.

Araştırmanın çalışma grubunu oluşturan çocukların annelerinin eğitim durumlarına göre müziğe ilişkin tutumları arasında anlamlı bir fark bulunmamıştır. Yani çocukların müziğe ilişkin tutumları annenin eğitim durumundan önemli ölçüde etkilenmemektedir. Bu konudaki beklenti annenin eğitim düzeyinin yüksekliğinin çocuğun müziğe ilişkin tutumunu olumlu olarak etkileyeceği yönündedir. Ancak araştırmanın bu konudaki sonucu beklenti doğrultusunda çıkmamıştır.

Araştırmanın çalışma grubunu oluşturan çocukların babalarının eğitim durumlarına göre de müziğe ilişkin tutumları arasında anlamlı bir farklılık bulunmamıştır. Yani çocukların müziğe ilişkin tutumları babanın eğitim durumundan pek etkilenmemektedir. Yukarıda annenin eğitim durumunda olduğu gibi literatürde bu konuda da farklı sonuçlar ortaya koyan bazı araştırmalar bulunmaktadır. Örneğin Özmenteş (2012), Umuzdaş ve Umuzdaş (2015) tarafından yapılan araştırmada babanın eğitim durumuna göre çocukların müziğe ilişkin tutumlarında anlamlı bir farklılığa rastlanmazken, Koca (2013) tarafından yapılan araştırmalarda babanın eğitim durumuna göre çocukların müziğe ilişkin tutumlarında anlamlı farklılık olduğu belirlenmiştir. Bu araştırma ve diğer adı geçen araştırmaların bulgularını dikkate alarak babanın eğitim durumunun çocukların müziğe ilişkin tutumlarının önemli bir belirleyicisinin olmadığı sonucuna varılabilir. Çocukların babalarının eğitim durumuna göre sosyal beceri düzeylerinde de anlamlı bir farklılık bulunmamıştır. Bu bulgunun da bu konudaki beklentiye uygun olamadığı söylenebilir.

Araştırmanın çalışma grubunu oluşturan çocukların bir müzik enstrümanı çalıp çalmama durumlarına göre müziğe ilişkin tutumlarında anlamlı bir farklılık olduğu bulunmuştur. Bir müzik enstrümanı çaldığını belirten çocukların müziğe ilişkin tutumlarının müzik enstrümanı çalmadığını belirtenlerinkinden daha yüksek olduğu saptanmıştır. Bu bulgu herhangi bir müzik enstrümanı çalmanın müziğe yönelik tutumu olumlu yönde etkilediğini ve geliştirdiğini göstermektedir. Çocukların herhangi bir müzik enstrümanı ile tanıştırılmaları ve müzik enstrümanı çalma yönünde teşvik edilmeleri, müziğe ve müzik enstrümanlarına yönelik algılarını olumlu olarak etkileyecek ve müzik yeteneklerini geliştirecektir. Makobi'ye (1985) göre öğrenciler herhangi bir müzik enstrümanı ile karşılaşmazsa, müzik enstrümanı çalmak onlar için zor gelebilir. Eğer bir müzik öğretmeni en az bir müzik enstrümanı çalıyorsa, bu durum öğrencilerin müzik enstrümanı çalma yeteneklerini geliştirebilir. 
Araştırmanın bu konudaki diğer bulgusuna göre müzik enstrümanı çaldığını belirten çocukların sosyal beceri düzeylerinin çalmadığını belirtenlere göre daha yüksek olduğu ortaya çıkmıştır. Bu da çocukların müzik enstrümanı çalarken gerek bu konuda kurs veren kişi ile gerekse kurs alan diğer bireylerle iletişim halinde bulunarak sosyal beceri açısından olumlu davranışlar kazanmalarından kaynaklanabilir. Bu konudaki literatürde müzik enstrümanı çalıp çalmamaya göre sosyal beceri düzeylerini inceleyen doğrudan bir araştırmaya rastlanılmasa da, Bebek'e (2007) göre çocukların, kendilerini ifade edebilecekleri müziksel etkinliklere ve grup çalışmalarına katılmaları onların sosyalleşmesine katkı sağlayacaktır. Erken yaşlarda müzikle tanıştırılan çocuklarda, verimli bir müzik eğitimi ortamına katılan ve enstrüman çalmayı öğrenen bireylerde bilişsel ve akademik olarak olumlu yönde gelişmeler sağlandığı, yapılan çalışmalarla ortaya konmuştur (Gün, Duru ve Demirtaş, 2016 ). Bir müzik enstrümanı çalmanın sosyal becerinin gelişmesine katkı sağlaması beklenen bir durumdur. Ancak bu konuda daha belirgin sonuçlar elde edilebilmesi için ek araştırmalara ihtiyaç olduğu söylenebilir.

Araştırmanın çalışma grubunu oluşturan çocukların bir müzik kursu alıp almama durumlarına göre müziğe ilişkin tutumlarında anlamlı bir fark bulunmuştur. Bir müzik kursu aldığını belirten çocukların almayanlara göre müziğe ilişkin tutumlarının daha yüksek olduğu belirlenmiştir. Bu bulgu, bir müzik kursuna katılmanın müziğe yönelik olumlu tutum geliştirmede katkısının olduğunu göstermektedir. Literatürde ulaşılan bazı araştırmaların bulguları bu araştırmanın bu yöndeki bulgusunu destekler niteliktedir. Öztopalan'nın (2007) özel ve devlet okullarının 6,7 ve 8 . sınıfında okuyan öğrenciler üzerinde yaptığı çalışmada okul içi ve okul dışı müziksel etkinliklere katılan öğrencilerin müziğe yönelik tutumları, katılmayan öğrencilere göre daha yüksek bulunmuştur. İnceel (2011) tarafindan yapılan araştırmada okul dışında müzikle ilgilenen öğrencilerin müziğe ilişkin tutumlarının ilgilenmeyenlere göre daha yüksek olduğu saptanmıştır. Afacan ve Özgür'ün (2016) araştırmasında da okul içi ya da okul dışındaki müzikle ilgili etkinliklere katılan öğrencilerin müziğe yönelik tutumlarının daha yüksek olduğu ortaya çıkmıştır. Gerek adı geçen araştırmaların bulguları gerekse bu araştırmanın bu konudaki bulgusu, herhangi bir müzik kursuna ya da müziksel etkinliklere katılmanın müziğe yönelik olumlu tutumların gelişmesinde etkili olduğunu göstermektedir. Araştırmanın bu konuyla ilgili diğer bir bulgusuna göre, çocukların herhangi bir müzik kursu alıp almamalarına göre sosyal beceri düzeylerinde anlamlı bir fark bulunmuştur. Bir müzik kursu aldığını belirten çocukların almayanlara göre sosyal beceri düzeylerinin daha yüksek olduğu belirlenmiştir. Literatürde bu bulguyu destekler nitelikte bazı çalışmalara rastlanmıştır. Heyworth'un (2013) sosyal becerilerin müzikle geliştirilmesine yönelik çalı̧̧asında, müzik aracılığı ile ögrencilerin daha katılımcı bireyler haline geldiği ve kendilerini okulun bir parçası olarak hissettikleri gözlemlenmiştir. Çalışmanın sonucuna göre müzik, çocuklarda benlik saygısı artışı, aidiyet duygusu, işbirliği, öğrenmeye aktif katılım sağlayarak çocukların sosyal, duygusal ve eğitsel gelişimini desteklemektedir. Küpana (2015) tarafindan yapılan bir literatür çalışmasında ise sosyal ve duygusal öğrenme ile müzik eğitimi ilişkisini ortaya koymak amaçlanmıştır. Çalışmada ulaşılan sonuçlar arasında; müziğin kendini ifade etmenin bir yolu olduğu, grup deneyimini ve sosyal-duygusal öğrenme becerilerini geliştirdiği şeklinde sonuçlar bulunmuştur. Schellenberg, Corrigall, Dys ve Malti'nin (2015) yapmış oldukları çalışmada, çocukluk döneminde grupla müzik eğitiminin sosyal beceri üzerine etkisi araştırılmıştır. Araştırmada, 10 aylık müzik eğitimine katılan 3. ve 4. sınıf düzeyindeki öğrencilerin grupla müzik eğitimine başlamadan önceki ve başladıktan sonraki sosyal becerileri karşılaştırılmıştır. Araştırmadan elde edilen bulgulara göre, grupla müzik eğitiminin öğrencilerin sosyal becerilerinin geliştirilmesini kolaylaştırdığı saptanmıştır.

Gerek bu konudaki araştırma bulgularına, gerekse bu araştırmada elde edilen bu konudaki bulguya dayalı olarak bir müzik kursuna ya da müziksel etkinliklere katılmanın sosyal beceri üzerinde olumlu etkilerinin olduğu ve sosyal beceriyi geliştirdiği söylenebilir.

\section{Sonuç ve Öneriler}

Araştırmada ulaşılan genel sonuçlar ve bu sonuçlara dayalı öneriler aşağıda verilmiştir:

1. Çocukların müziğe ilişkin tutumları ile sosyal beceri düzeyleri arasında pozitif yönde anlamlı bir iliş̧ki olduğu bulunmuştur. Buna göre, çocukların müziğe ilişkin tutumları arttıkça sosyal beceri düzeylerinin de arttığı sonucuna varılmıştır.

2. Çocukların Ankara'da yaşadıkları merkez ilçelere göre müziğe yönelik tutumlarında anlamlı bir farklılık bulunurken, sosyal beceri düzeylerinde anlamlı bir fark bulunmamıştır.

3. Çocukların cinsiyetlerine göre hem müziğe yönelik tutumlarında hem de sosyal beceri düzeylerinde anlamlı bir farklılık bulunmuştur. Kızların müziğe yönelik tutumları ve sosyal beceri düzeylerinin erkeklerden daha yüksek olduğu sonucuna ulaşılmıştır.

4. Çocukların yaşlarına göre hem müziğe yönelik tutumlarında hem de sosyal beceri düzeylerinde anlamlı bir farklılık bulunmuştur. 13 yaşındaki çocukların müziğe yönelik tutumlarının 14 yaşındaki çocuklardan daha 
yüksek olduğu ortaya çıkmıştır. Diğer yandan 12 yaşındaki çocukların sosyal beceri düzeyleri 13 ve 14 yaşındakilere göre daha yüksek bulunmuştur.

5. Çocukların okuldaki başarı algılarına göre hem müziğe ilişkin tutumlarında hem de sosyal beceri düzeylerinde anlamlı bir fark olduğu bulunmuştur. Okuldaki başarı algısı yüksek olan çocukların müziğe ilişkin tutumları ve sosyal beceri düzeyleri başarı algısı orta ve düşük olan çocuklara, okuldaki başarı algısı orta olan çocukların da düşük olanlara göre müziğe ilişkin tutumları ve sosyal beceri düzeyleri daha yüksek bulunmuştur.

6. Çocuklarının annelerinin ve babalarının eğitim durumuna göre hem müziğe ilişkin tutumlarında hem de sosyal beceri düzeylerinde anlamlı bir farklılık bulunmamıştır.

7. Bir müzik enstrümanı çaldığını belirten çocukların müziğe ilişkin tutumları ve sosyal beceri düzeylerinin bir enstrüman çalmadığını belirtenlere göre daha yüksek olduğu sonucuna varılmıştır.

8. Bir müzik kursu aldığını belirten çocukların müziğe ilişkin tutumları ve sosyal beceri düzeylerinin müzik kursu almadığını belirtenlere göre daha yüksek olduğu sonucuna varılmıştır.

Araştırmanın bulgularına dayalı olarak aşağıdaki öneriler sunulabilir:

1. Çocukların müziğe ilişkin tutumları arttıkça sosyal beceri düzeyleri de arttığından, sosyal beceriyi geliştirmede katkı sağlamak amacıyla çocuklarının müziğe olan ilgi ve tutumlarını artırmak, müziği sevdirmek amacıyla çeşitli müziksel etkinlikler planlanıp uygulanabilir.

2. Araştırmada hem müziğe ilişkin tutumlarda hem de sosyal beceri düzeylerinde erkek çocuklar kızlara göre daha düşük puan sergiledikleri için, müziksel etkinlikler planlanıp uygulanırken kız çocuklarının yanında özellikle erkek çocuklarının da bu sürece katılmalarını teşvik etmekte yarar vardır.

3. Okuldaki başarı algısı yüksek olan çocukların hem müziğe ilişkin tutumları hem de sosyal beceri düzeyleri daha yüksek bulunduğundan, özellikle okuldaki başarısı düşük olan çocukların müziksel ve sosyal etkinliklere katılmaları teşvik edilerek onların da kendilerini daha olumlu algılamalarına ve okuldaki başarılarını yükseltmelerine katk1 sağlanabilir.

4. Bir müzik enstrümanı çalıyor olmak müziğe ilişkin tutum ve sosyal beceri üzerinde olumlu etki yarattığından, çocukların müzik enstrümanları ile tanışmaları, ilgi duydukları enstrümanı çalmaları sağlanarak onların müziğe ilişkin tutumları ve sosyal beceri düzeyleri arttırılabilir.

5. Bir müzik kursuna katılmış olmak müziğe ilişkin tutum ve sosyal beceriye katkı sağlayıcı olduğu için çocuklara yönelik çeşitli müzik kursları ve etkinlikleri düzenlenebilir.

6. Bu araştırma 12-14 yaş grubu çocuklar üzerinde yürütülmüştür. Farklı yaş grupları üzerinde de (örneğin 6-11 yaş, 15-18 yaş gibi) benzer bir araştırma yapılabilir.

7. Bu araştırmada müziğe ilişkin tutum ile sosyal beceri düzeyi arasındaki ilişki incelenmiştir. Müziğe ilişkin tutum ile başka değişkenler (örneğin benlik kavramı, benlik saygısı, öz yeterlilik gibi) arasındaki ilişkiyi inceleyen araştırmalar yapılabilir.

8. Müziğe yönelik tutumu ve sosyal beceriler geliştirmeyi sağlayıcı deneysel araştırmalar yapılabilir.

\section{Kaynakça}

Afacan, Ș. ve Özgür, Ü. (2016). 6 ve 7. sınıf öğrencilerinin müzik dersine ilişkin tutumlarının çeşitli değişkenler açısından incelenmesi. UHMAD Uluslararası Hakemli Müzik Araştırmaları Dergisi, 7: 1-24. ID:54 K:104

Aktı, S. (2011). İlköğretim Sekizinci Sinıf Öğrencilerinin Medya Okuryazarlı̆̆ ile Sosyal Beceri Düzeyleri Arasındaki İlişkinin Belirlenmesi. (Yayınlanmamış yüksek lisans tezi). Fırat Üniversitesi Sosyal Bilimler Enstitüsü.

Akkök, F. (1999). Illköğretimde sosyal becerinin geliştirilmesi: ögretmen el kitabı. İstanbul: Özgür Yayınları.

Akkuş, Z. (2005). İlköğretim 5. Sinıf Öğrencilerinin Sosyal Becerilerinin Özsaygı ve Denetim Odă̆ ile İlişkisi. (Yayınlanmamış yüksek lisans tezi). Gazi Üniversitesi Eğitim Bilimleri Enstitüsü.

Arslanoğlu, C. (2010). Spor Yapan ve Spor Yapmayan Ortä̈ğretim Öğrencilerinin Sosyal Beceri Düzeylerinin Karşılaş̧tırılması. (Yayınlanmamış yüksek lisans tezi). Gazi Üniversitesi Eğitim Bilimleri Enstitüsü Beden Eğitimi Ve Spor Öğretmenliği Anabilim Dalı.

Aslantaş H. (2016). Yatılı bölge ortaokulu öğrencilerinin müzik dersine ilişkin tutumlarının farklı değişkenler açısından incelenmesi. Mehmet Akif Ersoy Üniversitesi Eğitim Fakültesi Dergisi, 37: 154-165. 
Aydın, O. (1987). Davranış bilimlerine giriş. (Yayın No:173). Eskişehir: Anadolu Üniversitesi Açık Öğretim Fakültesi.

Babacan, E., Babacan, M.D. ve Pirgon,Y. (2011). İlköğretim 2. kademe öğrencilerinin müzik dersine yönelik tutumlarının incelenmesi. Selçuk Üniversitesi Ahmet Keleşoğlu Eğitim Fakültesi Dergisi, 32: 325-336.

Bacanlı, H. (1999). Sosyal beceri ĕgitimi. Ankara: Nobel Yayınları.

Bahadır, Z. (2011). Beden Ĕ̌gitimi ve Sporda Kullanılan Farklı Öğretim Yöntemlerinin (İşbirliğine Dayalı Öğrenme ve Alıştırma Yöntemi) Öğrencilerin Ders Tutumlarına ve Sosyal Becerilerine Etkisi. (Yayınlanmamış doktora tezi). Gazi Üniversitesi Eğitim Bilimleri Enstitüsü.

Balyan, M. (2009). Illköğretim 2. Kademe Ve Ortä̈ğretim Kurumlarındaki Öğrencilerin Beden Ĕ̆itimi Dersine Yönelik Tutumları, Sosyal Beceri ve Özyeterlik Düzeylerinin Karşılaşstırılması. (Yayınlanmamış yüksek lisans tezi). Ege Üniversitesi Sağlık Bilimleri Enstitüsü Sporda Psiko-Sosyal Alanlar Anabilim Dalı.

Bebek, F. (2007). Illköğretimde Ders İçi ve Ders Dışı Müziksel Etkinliklerin Öğrenci ve Öğretmenlerin Müziksel Davranış ve Yaşantılarına Etkileri. (Yayınlanmamış yüksek lisans tezi). Ankara, Gazi Üniversitesi Eğitim Bilimleri Enstitüsü.

Büyüköztürk, Ş., Çakmak, E., Akgün, Ö., Karadeniz, Ş. ve Demirel, F. (2011). Bilimsel araştırma yöntemleri, (9. Bask1). Ankara: Pegem Akademi.

Brown, Mary J. (1986). Student Attitude Towards Instrumental Music Education During the First Year of Instruction, Doctoral Dissertation. The Graduate School of The Ohio State University.

Cerrahoğlu, S. (2002). Sosyal Beceri Ĕ̆itiminin İlköğretim Öğrencilerinin Öz Kavramı Düzeylerine Etkisi. (Yayınlanmamış yüksek lisans tezi). On Dokuz Mayıs Üniversitesi Sosyal Bilimler Enstitüsü.

Coşkun, N. (2011). İlköğretim 4. ve 5. Sinıflarda Sosyal Beceri Düzeyi ile Sosyal Bilgiler Dersine Yönelik Tutumların Çeşitli Değişkenler Açısından Incelenmesi. (Yayınlanmamış yüksek lisans tezi). Atatürk Üniversitesi Eğitim Bilimleri Enstitüsü İlköğretim Ana Bilim Dalı.

Çiriş, V. (2014). Spor Yapan ve Yapmayan Ortaokul Öğrencilerinin Sosyal Beceri Düzeylerinin Karşılaştırılması. (Yayınlanmamış yüksek lisans tezi). Gazi Üniversitesi Sağlık Bilimleri Enstitüsü.

Cüceloğlu, D. (1991). Insan ve davranışı: Psikolojinin temel kavramları. İstanbul: Remzi Kitabevi.

Denac, Olga. (2008). A case study of preschool children's musical interest at home and at school. Early Childhood Education Journal, 35(5): 439-444.

Dermez, H.G. (2008). İlköğretim 4. ve 5. Sınıf Öğrencilerinin Sosyal Beceri Düzeylerinin Bazı Değişkenler Açısından Incelenmesi. (Yayınlanmamış yüksek lisans tezi). Afyonkarahisar Kocatepe Üniversitesi Sosyal Bilimler Enstitüsü İlköğretim Ana Bilim Dalı.

Duran, M., Çeliköz, N., Topaloğlu, A.Ö. (2013). Ortaokul öğrencilerinin sosyal beceri düzeylerinin belirlenmesi. İönü Üniversitesi Eğitim Fakültesi Dergisi, 14(2): 121-137.

Durualp, E. (2014). Ergenlerin sosyal duygusal öğrenme becerilerinin cinsiyet ve sınıfa göre incelenmesi. The Journal of Academic Social Science Studies, 26: 13-25.

Erdem, C. (2011). Ergenin müzik ile iletişimi. Türk Pediatri Araştırmaları Dergisi, Özel Sayı 46: 19-21.

Erdoğan, F. (2002). İlkögrretim II. Kademe Öğrencilerinde Sosyal Becerilerin Sosyo-Ekonomik Düzey, Cinsiyet ve Yaş ile İlişkisi. (Yayınlanmamış yüksek lisans tezi). Gazi Üniversitesi Eğitim Bilimleri Enstitüsü.

Ergen, D. ve Bilen, S. (2010). İlköğretim düzeyinde eşlikli çalmaya dayalı keman eğitiminin entonasyon, özgüven ve tutum üzerindeki etkisi. Batı Anadolu Eğitim Bilimleri Dergisi (BAED), 1(1): 23-32.

Erkan, S. (2011). Gelişim psikolojisinde temel kavramlar (s.27-50). Ĕgitim psikolojisi. 3. Bask1. (Editörler: Y. Özbay ve S. Erkan). Ankara: Pegem Akademi.

Erol, İ. L. (1988). Ortaöğretim Öğrencilerinin Müziğe İlgi Düzeyleri ile Akademik Başarı Düzeyleri Arasındaki İlişkinin Araştırılması. (Yayınlanmamış yüksek lisans tezi). Gazi Üniversitesi Fen Bilimleri Enstitüsü.

Guilmartin, L. (2015). Creating harmony: How music can support social emotional development. http://www.parenttoolkit.com/social-and-emotional-development. 17.07.2017 tarihinde erişilmiştir.

Gülhan, G. (2012). 10-12 Yaş Grubu İlköğretim Öğrencilerinin Sosyal Beceri Düzeyleri Üzerine Ĕ̆itsel Oyunların Etkisi. (Yayınlanmamış yüksek lisans tezi). Gazi Üniversitesi Eğitim Bilimleri Enstitüsü Beden Eğitimi ve Spor Öğretmenliği Anabilim Dalı. 
Gün, E., Duru, E. G. ve Demirtaş, H. O. (2016). Müzik eğitiminin bilişsel gelişime etkisi. The Journal of Academic Social Science Studies, 50: 117-124.

Heyworth, J.N. (2013). Developing social skills through music: The impact of general classroom music in an Australian lower socio-economic area primary school. Childhood Education, 89 (4): 234-242.

İnceel, S. (2011). İlköğretim Öğrencilerinin Müzik Dersine İlişkin Tutumlarl ile Türkçe ve Müzik Dersleri Akademik Başarıları Arasındaki İlişkinin Incelenmesi. (Yayınlanmamış yüksek lisans tezi). Marmara Üniversitesi Eğitim Bilimleri Enstitüsü Güzel Sanatlar Eğitimi Anabilim Dalı.

Kağıtçıbaşı, Ç. (1998). İnsan ve insanlar. Gözden geçirilmiş 7. Baskı. İstanbul: Evrim Basım Yayın ve Dağıtım.

Kağıtçıbaşı, Ç. (2010). Günümüzde insan ve insanlar sosyal psikolojiye giriş. 12. Basım. İstanbul: Evrim Yayınevi.

Kaplan, A. (2013). Kültürel müzikoloji. İstanbul: Bağlam Yayıncıl1k.

Karakaya, İ. (2012). Bilimsel araştırma yöntemleri. (s 55-84), Bilimsel araştırma yöntemleri. (Ed. Abdurrahman Tanrı̈̆̆gen) Ankara: Anı Yayınları.

Kaya, A. (2010). İlköğretim 8. Sinıf Düzeyindeki Öğrencilerin Müzik Dersine İlişkin Görüşlerinin Çeşitli Değişkenler Açısından Değerlendirilmesi. (Yayınlanmamış yüksek lisans tezi). Uludağ Üniversitesi Sosyal Bilimler Enstitüsü Güzel Sanatlar Eğitimi Anabilim Dalı.

Keskin, A. (2007). İlköğretim Öğrencilerinin Ders Başarıları İle Sosyal Beceri Durumlarının Incelenmesi. (Yayınlanmamış yüksek lisans tezi). Celal Bayar Üniversitesi Sosyal Bilimler Enstitüsü.

Kılıç, I. (2016). Ortaokul öğrencilerinin müzik ile ilgili görüşlerinin incelenmesi. Eğitim ve Öğretim Araştırmaları Dergisi, 5(3): 360-371.

Koca, Ş. (2013). Ortaöğretim öğrencilerinin müzik dersine yönelik tutumlarının incelenmesi. Ç.Ü. Sosyal Bilimler Enstitüsü Dergisi, 22(2): 209-222.

Kocaarslan, B. (2009). Genel Müzik Ĕgitimi Alan ilköğretim Öğrencilerinin Müzik Dersine ilişkin tutum, Müzikal Özgüven ve Motivasyon Düzeylerinin Karşılaştırılması. (Yayınlanmamış yüksek lisans tezi). İstanbul, Marmara Üniversitesi Eğitim Bilimleri Enstitüsü.

Kocabaş, A. (1997). Temel eğitim II. kademe öğrencileri için müziğe ilişkin tutum ölçeğinin geçerlik ve güvenirlik çalışması. Hacettepe Üniversitesi Eğitim Fakültesi Dergisi, (13): 141-145.

Küpana N. (2015). Social emotional learning and music education. Sanat Eğitimi Dergisi, 3(2): 75-88.

Makar, E. (2016). Spor Ĕgitimi Gören Öğrencilerin, Sosyal Beceri, Fiziksel Benlik Alglsı ve Fiziksel Aktivite Düzeyleri Arasındaki İlişkinin İncelenmesi. (Yayınlanmamış yüksek lisans tezi). Bartın Üniversitesi, Eğitim Bilimleri Enstitüsü.

Makobi, T. S. (1985). Factors affecting Music Education in Primary Schools in Kenya. M. Ed. Research Project, Nairobi.

Nacakcı, Z. (2006). İlköğretim öğrencilerinin müzik dersine ilişkin tutumları. Ulusal Müzik Eğitimi Sempozyumu Bildirisi, 26-28 Nisan 2006, Pamukkale Üniversitesi Eğitim Fakültesi, Denizli.

Önalan Akfirat, F. (2006). Sosyal yeterlilik, sosyal beceri ve yaratıcı drama. Yaratıcı Drama Dergisi, 1(1): 3958.

Özdemir, G. ve Yıldız, G. (2010). Genel gelişim sürecinde müziksel gelişim. Mehmet Akif Ersoy Üniversitesi Sosyal Bilimler Enstitüsü Dergisi, 2(2): 80-94.

Özmenteş, S. (2012). İlköğretim öğrencilerinin evdeki müziksel ortamları, müzik dersine yönelik tutumları ve kişisel değişkenleri arasındaki ilişkiler. Ĕgitim ve Bilim, 37(163): 53-66.

Öztopalan, E. (2007). İlköğretim Düzeyindeki Özel Okullar ile Devlet Okullarının 6, 7 ve 8. Sınıf Öğrencilerinin Müzik Dersine İlişkin Tutumları ve Akademik Başarıları Arasındaki İlişki. (Yayınlanmamış yüksek lisans tezi). Dokuz Eylül Üniversitesi Eğitim Bilimleri Enstitüsü Güzel Sanatlar Eğitimi Anabilim Dalı.

Saruhan, Ş. ve Deniz, J. (2011). Temel eğitim II. kademe öğrencilerinin müzik dersine karşı tutumları. Ilköğretim Online, 10(2): 695-702.

Senemoğlu, N. (2013). Gelişim, öğrenme ve öğretim. 23. Baskı. Ankara: Yarg1 Yayınevi. 
Schellenberg, E. ve diğerleri. (2015). Group music training and children's prosocial skills. Plos One, 10(10): e0141449.

Şad, E.D. (2007). Akranları Tarafindan Reddedilen ve Kabul Edilen İlköğretim II. Kademe Öğrencilerinin Özsaygı, Sosyal Beceri, Davranış Problemleri ve Okul Başarılarının Karşılaştırılması. (Yayınlanmamış yüksek lisans tezi). Ankara Üniversitesi Eğitim Bilimleri Enstitüsü Eğitim Bilimleri Anabilim Dalı.

Şaşkın, Önder. (2010). Illköğretim Okulları 7 ve 8. Sınıf Öğrencilerinin Sosyal Becerilerinin Geliştirilmesi ve Değerlendirilmesi Üzerine Küçükçekmece’de Bir Araştırma. (Yayınlanmamış yüksek lisans tezi). Beykent Üniversitesi Sosyal Bilimler Enstitüsü.

Tabachnick, B.G. ve Fidell, L.S. (2013). Using multivariate statistics (sixth ed.) Boston: Pearson.

Tosun Sümer, E. (2008). İlköğretim 6. ve 7. Sinıf Öğrencilerinin Ebeveynlerinin Sosyal Kaygıları ile Çocukların Sosyal Beceri Düzeyleri Arasındaki İlişkinin Incelenmesi. (Yayınlanmamış yüksek lisans tezi). Gazi Üniversitesi Eğitim Bilimleri Enstitüsü.

Uçan, A. (2005). Müzik eğitimi. 3. Basın. Ankara: Evrensel Müzikevi.

Uçan, A., Yıldız, G. ve Bayraktar, E. (1999). İlköğretimde etkili öğretme ve öğrenme ögrretmen el kitabı. modül 9 ilkögretimde müzik ögretimi. Burdur.

Uluocak, S. ve Tufan, E. (2011). İlköğretim altıncı sınıf öğrencilerinin müzik dersine ilişkin tutumlarının farklı değişkenler açısından incelenmesi. Kastamonu Eğitim Dergisi, 19(3): 991-1002.

Umuzdaş, M.S. ve Umuzdaş S. (2015). 8. sınıf öğrencilerinin müzik dersine ilişkin tutumlarının çeşitli değişkenlere göre incelenmesi. Uluslararası Türk Eğitim Bilimleri Dergisi, Ekim: 273-281.

Uslu, R. (2006). Müzikoloji ve kaynakları. İstanbul: İTÜ Vakfı Yayınları.

Varış, Y. A. ve Cesur, D. (2012). Ortaöğretim öğrencilerinin müzik dersine ilişkin tutumları ile akademik başarıları arasındaki ilişki. E-Journal of New World Sciences Academy, 7(4): 318-333.

Wanjala, Henry N., (2011). The relationship between attitudes towards music and achievement. International Journal of Current Research, 3 (8): 140-145.

Yiğit, R. (2008). İlköğretim II. Kademe Öğrencilerinin Depresyon Ve Sosyal Beceri Düzeylerinin Benlik Saygısı ve Bazı Değişkenler Açısından Karş̧laştırmalı Olarak Incelenmesi. (Yayınlanmamış doktora tezi). Selçuk Üniversitesi Sosyal Bilimler Enstitüsü.

Yiğit, R. ve Yılmaz, H. (2011). İlköğretim II. kademe öğrencilerinin sosyal beceri düzeyleri ile benlik saygıs1 arasındaki ilişkinin incelenmesi. Selçuk Üniversitesi Ahmet Keleşoğlu Eğitim Fakültesi Dergisi, (31): 335 347.

Yurdakavuştu, Y. (2012). İlköğretim Öğrencilerinde Duygusal Zekâ ve Sosyal Beceri Düzeyleri. (Yayınlanmamış yüksek lisans tezi). Dokuz Eylül Üniversitesi Eğitim Bilimleri Enstitüsü. 


\section{EXTENDED ABSTRACT}

In this study, the relationship between music attitudes and social skill levels of 12-14 age group was determined and according to some variables, children's attitudes towards music and social skills levels were examined. Since the existing and current situation about the variables was tried to be determined, descriptive research model was used in the research. The participants included a total of 803 individuals 424 female (52.8\%) and 379 male $(47.2 \%)$ selected from six secondary schools in the districts of Altındağ, Çankaya, Etimesgut, Mamak and Yenimahalle in Ankara during the academic year 2016-2017 form. In the study, the Scale of Attitude towards Music was used to determine children's attitudes towards music. Furthermore, the Social Skill Scale for Children was utilized to determine their social skill levels and Personal Information Form developed by the researcher were used to collect the related demographic information. In the analysis of the collected data, frequency, percentage, Pearson Moments Multiplication Correlation Coefficient, t-test, One way ANOVA and Tukey HSD test were used by means of SPSS 21 program in the study.

Findings obtained in the research can be summarized as follows:

1. There was a significant positive correlation between children's attitudes towards music and social skills levels. Accordingly, social attitudes increase as children's attitudes towards music increase.

2. A significant difference was found in the attitudes of children towards music according to the central districts they lived in Ankara, but no significant difference was found in their social skills levels.

3. A significant difference was found in both children's attitudes towards music and social skills levels according to their genders. Girls' attitudes towards music and social skills were found to be higher than boys'.

4. A significant difference was found in both children's attitudes towards music and social skills according to their age. It turns out that the attitudes of 13-year-olds to music are higher than those of 14-year-olds. On the other hand, the social skills of children aged 12 years were found to be higher than those aged 13 and 14 years.

5. A significant difference was found in both children's attitudes towards music and social skills according to their academic achievement perceptions. Children with high academic achievement attitudes were found to have a higher level of attitudes towards music and social skills than children with medium and low achievement perceptions. Similarly, children with a medium academic achievement perception were observed to have a higher level of attitude toward music and social skill level than children with a low achievement perception.

6. There was no significant difference in children's attitudes towards music and social skills levels according to their parents' educational status.

7. According to whether to play a musical instrument different from flute and melodicas, there was a significant difference in children's attitudes towards music as well as social skills levels. Children who stated that they played a musical instrument were found to have a higher attitude towards music and social skill levels than children who indicated that they did not play an instrument.

8. There was a significant difference in children's attitudes towards music as well as their social skill levels according to whether they took any music courses or not. Children who said that they had a music course were found to have a higher attitude towards music and social skill levels than those who indicated that they did not attended a music course. 